\title{
Digital Technologies in the Organization of Accounting and Control of Calculations for Tax Liabilities of Budgetary Institutions
}

\author{
SVITLANA SYRTSEVA ${ }^{1}$, SVITLANA BURLAN ${ }^{2}$, NATALIA KATKOVA ${ }^{3}$, YULIIA CHEBAN ${ }^{4}$, \\ TETIANA PISOCHENKO ${ }^{5}$, ALLA KOSTYRKO ${ }^{6}$ \\ ${ }^{1}$ Department of Accounting and Taxation, MYKOLAYIV NATIONAL AGRARIAN UNIVERSITY, UKRAINE, \\ E-mail: lana.bond@ukr.net, ORCID: http://orcid.org/0000-0002-4816-4579 \\ ${ }^{2}$ Department of Accounting and Auditing, PETRO MOHYLA BLACK SEA NATIONAL UNIVERSITY, UKRAINE, \\ E-mail: audit.svetla@gmail.com, ORCID: http://orcid.org/0000-0002-4816-4579 \\ ${ }^{3}$ Department of Accounting and Economic Analysis, ADMIRAL MAKAROV NATIONAL UNIVERSITY OF \\ SHIPBUILDING, UKRAINE, E-mail: nataliavkatkova@gmail.com, ORCID: http://orcid.org/0000-0002-4816-4579 \\ ${ }^{4}$ Department of Accounting and Taxation, MYKOLAYIV NATIONAL AGRARIAN UNIVERSITY, UKRAINE , \\ E-mail: cheban@mnau.edu.ua, ORCID: http://orcid.org/0000-0002-4816-4579 \\ ${ }^{5}$ Department of Accounting and Taxation, MYKOLAYIV NATIONAL AGRARIAN UNIVERSITY, UKRAINE, \\ E-mail: pisochenko@mnau.edu.ua, ORCID: http://orcid.org/0000-0002-4816-4579 \\ ${ }^{6}$ Department of Accounting and Taxation, MYKOLAYIV NATIONAL AGRARIAN UNIVERSITY, UKRAINE, \\ E-mail: agkostyrko@mnau.edu.ua, ORCID: http://orcid.org/0000-0002-4816-4579
}

\begin{abstract}
The purpose of the study is to identify areas and form mechanisms for improving the organization of accounting and control of calculations for tax liabilities of budgetary institutions based on the introduction of digital technologies. The relevance of this study is due to the need to solve the problem of modernization of the tax administration system by implementation modern information and analytical resource of the tax service. The study proved that creation of a modern information and analytical resource of the tax service optimizes the system of accounting and control, which will lead to the introduction of more effective mechanisms for tax administration, de-shadowing of the economy and increasing control over cash circulation. Digitization of accounting and control of calculations of tax liabilities of budgetary institutions will help increase the level of tax culture, which will also significantly contribute to improving tax discipline.
\end{abstract}

Keywords: Digital Technologies; Organization of Accounting and Control; Budgetary Institution; Calculations for Tax Liabilities; Tax Culture.

JEL classification: JEL M41, O17

Received: April 09, 2021

Accepted: June 16, 2021 


\title{
Tecnologías Digitales en la Organización de la Contabilidad y el Control de los Cálculos de las Obligaciones Fiscales de las Instituciones Presupuestarias
}

\author{
SVITLANA SYRTSEVA ${ }^{1}$, SVITLANA BURLAN ${ }^{2}$, NATALIA KATKOVA ${ }^{3}$, YULIIA CHEBAN $^{4}$, \\ TETIANA PISOCHENKO ${ }^{5}$, ALLA KOSTYRKO ${ }^{6}$ \\ ${ }^{1}$ Department of Accounting and Taxation, MYKOLAYIV NATIONAL AGRARIAN UNIVERSITY, UKRAINE, \\ E-mail: lana.bond@ukr.net, ORCID: http://orcid.org/0000-0002-4816-4579 \\ ${ }^{2}$ Department of Accounting and Auditing, PETRO MOHYLA BLACK SEA NATIONAL UNIVERSITY, UKRAINE, \\ E-mail: audit.svetla@gmail.com, ORCID: http://orcid.org/0000-0002-4816-4579 \\ ${ }^{3}$ Department of Accounting and Economic Analysis, ADMIRAL MAKAROV NATIONAL UNIVERSITY OF \\ SHIPBUILDING, UKRAINE, E-mail: nataliavkatkova@gmail.com, ORCID: http://orcid.org/0000-0002-4816-4579 \\ ${ }^{4}$ Department of Accounting and Taxation, MYKOLAYIV NATIONAL AGRARIAN UNIVERSITY, UKRAINE , \\ E-mail: cheban@mnau.edu.ua, ORCID: http://orcid.org/0000-0002-4816-4579 \\ ${ }^{5}$ Department of Accounting and Taxation, MYKOLAYIV NATIONAL AGRARIAN UNIVERSITY, UKRAINE, \\ E-mail: pisochenko@mnau.edu.ua, ORCID: http://orcid.org/0000-0002-4816-4579 \\ ${ }^{6}$ Department of Accounting and Taxation, MYKOLAYIV NATIONAL AGRARIAN UNIVERSITY, UKRAINE, \\ E-mail: agkostyrko@mnau.edu.ua, ORCID: http://orcid.org/0000-0002-4816-4579
}

\section{RESUMEN}

El propósito del estudio es identificar áreas y formar mecanismos para mejorar la organización de la contabilidad y el control de los cálculos de las obligaciones fiscales de las instituciones presupuestarias sobre la base de la introducción de las tecnologías digitales. La relevancia de este estudio se debe a la necesidad de resolver el problema de la modernización del sistema de administración tributaria mediante la implementación de información moderna y recurso analítico del servicio tributario. El estudio demostró que la creación de un moderno recurso informativo y analítico del servicio tributario optimiza el sistema de contabilidad y control, lo que llevará a la introducción de mecanismos más eficaces para la administración tributaria, a la desestructuración de la economía y al aumento del control de la circulación de efectivo. La digitalización de la contabilidad y el control de los cálculos de las obligaciones fiscales de las instituciones presupuestarias ayudarán a aumentar el nivel de la cultura fiscal, lo que también contribuirá significativamente a mejorar la disciplina fiscal.

Palabras claves: Tecnologías digitales; Organización de la contabilidad y el control; Institución presupuestaria; Cálculos de las obligaciones fiscales; Cultura fiscal.

Clasificación JEL: JEL M41, O17

Recibido: 09 de abril de 2021

Aceptado: 16 de junio de 2021 


\section{Introduction}

The Sustainable Development Strategy "Ukraine - 2020" identifies the task of reforming the tax and customs sphere as one of the priority steps (Strategy "Ukraine - 2020"). This requires radical changes in the structure of this institution. Imperfection in the organization of accounting and control of calculations of tax liabilities, inefficiency of tax administration leads to significant government losses due to tax evasion, which negatively affects the formation of the budget. The mission of the newest state fiscal service is to educate the tax culture of citizens. The main idea of the radical transformation of the fiscal institution is to create a network of service centers (Sudomyr et al., 2020), which will have to fully meet the needs of paying customers on the basis of new technologies (Al-Htaybat \& von AlbertiAlhtaybat, 2017; Bhimani \& Willcocks, 2014 ; Mavlutova, 2021). Today, the main requirements for global administrations are digitization (Appelbaum et al., 2017; Eklund et al., 2018). The introduction of digital tools in the system of budget accounting and control is designed to increase the efficiency of specific processes and procedures and the quality and efficiency of the management process in budget organizations (Strategy, 2021; Sagan et al., 2020; Clarke, 2020). The system of organization of accounting and control is an element of the general system of management of budgetary institutions (European-Commission, 2016). The main advantages of using modern information technology to automate accounting procedures in budgetary institutions are:

- processing and storage of a large number of structurally identical units of accounting information (Gandomi \& Haider, 2015);

- the ability to sample the necessary information from a large amount of data (Goretzki et al., 2017);

- reliable and error-free implementation of mathematical calculations (Goretzki \& Messner, 2019; Perevozova, 2019);

- prompt receipt of data necessary for making sound management decisions (Bondarenko et al., 2021);

- multiple playback of actions, etc.

Experts have proven that the use of automation can completely solve the problem of accuracy of formation and efficiency of providing accounting information to civil servants of budgetary institutions for sound adoption and implementation of effective management decisions (Holmgren Caicedo et al., 2018; Bondarenko et al., 2020).

Ukraine is actively implementing the reform of the tax control system (Strategy "Ukraine - 2020"; Strategy, 2021). At the beginning of 2021 in Ukraine, the electronic office of the taxpayer used by more than 9 million users, almost $90 \%$ of declarations have made on the principle of "single window". In the test mode, the E-Receipt system was introduced, which is an important and necessary service for deshadowing the economy. However, there are difficulties in adapting tax control tools to the domestic public administration. The reason, among other things, is the uncertainty in the categorical apparatus, the lack of a concept of the information society in public management. The choice of the model of the organization of the account and control of calculations on tax obligations of budgetary institutions will allow to reveal strong and weak points of activity of public authorities, assess the level of quality of services, create a system of monitoring the effectiveness of public management processes based on digital technologies.

The main idea of the study is that the creation of a modern information and analytical resource of the tax service, the development and implementation of tailor-made information systems and networks is the basis for the formation of an effective control system of budgetary institutions. Research hypothesis: the condition for modernization of the tax service system in the implementation of state tax policy is the integration of information society principles into the system of accounting and control of tax liabilities of budgetary institutions based on the introduction of digital technologies (shaikh et al 2020). 


\section{Literary review}

Digital technologies have in recent years become the subject of scientific research in various aspects of life, including the development and transformation of accounting and tax control (Dunleavy et al., 2006; Accenture, 2018; Al-Htaybat \& von Alberti-Alhtaybat 2017). Experts in the field of accounting and technology have identified 10 technological trends that will significantly change the business and professional environment: mobile applications, big data, artificial intelligence and robotics, cybersecurity, education, cloud technologies, payment systems, virtual and augmented reality, digital services and social networks (ACCA / IMA, 2013). Technologies that will significantly change the key approaches in accounting in the near future are Al, Big Data, Blockchain, and Cybersecurity (IFAC, 2019). Widespread introduction of cloud technologies, acceleration of automation, introduction of Blockchain - these are the future trends in accounting (Forbes, 2018). A detailed review revealed the benefits of using cloud technologies in accounting.

Thus, the simplification of accounting documents through the migration of certain transactions to cloud electronic platforms, which will significantly change the accounting information system, will save costs (lonescu, et al., 2013). Research (Christauskas \& Misevicience, 2012) has shown that the introduction of digital technologies, including the Cloud, will help improve the quality of the decisionmaking process. In addition, cloud technologies create additional conditions and opportunities to communicate with clients and accountants in real time (Phillips, 2012). Data security can be ensured by a cloud provider, which eliminates the risks of unsynchronized data. Experts from the Financial Stability Board argue that Artificial intelligence (AI) technology will allow accounting data to justify management decisions, provide advice, develop strategies and conceptualize leadership (FSB, 2017). Robotic Process Automation (RPA) business automation technology accelerates process automation and $\mathrm{Al}$, which improves performance in the public sector (Deloitte, 2017).

This increases the accuracy and efficiency of the process of performing accounting tasks and the process using Al technology, creates conditions for effective control, while reducing operating costs. Al can provide better information through machine learning while helping to generate more transparent accounting information (Cho et al., 2018). Thus, positivist views on the conceptualization of digital technologies as determinants of influence on the organizational properties of systems formed in scientific research (Rikhardsson \& Yigitbasioglu, 2018; Rieg, 2018). Researchers establish causal links between the introduction of technology in the system of accounting and control (Weber, 2011; Schaltegger \& Zvezdov, 2015). Theoretical approaches concern the system of accounting and control in case of contingencies (Byrne \& Pierce, 2007; Rom \& Rohde, 2007), given the provisions of the theory of structuring (Caglio, 2003) and actor network theory (Rom \& Rohde, 2007; Dechow \& Mouritsen, 2005). The literature review showed that the effects of technology deterministic and this applies to all organizations.

That is, digital technologies can contribute to qualitative changes in the system of accounting and control of calculations of tax liabilities of budgetary institutions (Podgorna et al., 2020). The issue of transformation of the accounting and control system under the influence of digital technologies was paid attention by researchers (Quattrone, 2016; Dechow \& Mouritsen, 2005).

Dominance of technologies in the process of substantiation of management decisions (Wolf et al., 2015; Moll \& Yigitbasioglu, 2019), data-driven solutions (Horton \& Wanderley, 2018; Brown, 2019) reflects such a direction as promising for making timely and objective decisions. However, there is the opinion of scientists (Peter \& Robinson, 2014; Quattrone, 2016; Ulanoff, 2017) on the artificial reduction of the role of accounting, in particular, in the process of discussing and interpreting data and promoting the role of control in improving the accounting system. Such scientific research is especially relevant, given the transformational changes in the system of accounting and control, which are due to the reform of public services of fiscal policy.

Expediency of transformational changes in the control system calculations for tax liabilities of budgetary institutions is due, inter alia, to the problems of the budget deficit in recent years (Alghamdi et al 2017) The main indicators of the state budget of Ukraine for the period 2008-2020 presented in 
Table 1.

Table 1. Execution of the state budget of Ukraine from 2008 to 2020, (Indices, 2020)

\begin{tabular}{|c|c|c|c|c|c|c|c|c|}
\hline \multirow{2}{*}{ Years } & \multicolumn{2}{|c}{ Income } & \multicolumn{2}{c|}{ Expenses } & \multicolumn{2}{c|}{ Lending } & \multicolumn{2}{c|}{ Balance } \\
\cline { 2 - 9 } & $\begin{array}{c}\text { UAH } \\
\text { million }\end{array}$ & $\begin{array}{c}\% \text { of } \\
\text { GDP }\end{array}$ & $\begin{array}{c}\text { UAH } \\
\text { million }\end{array}$ & \% of GDP & $\begin{array}{c}\text { UAH } \\
\text { million }\end{array}$ & $\begin{array}{c}\% \text { of } \\
\text { GDP }\end{array}$ & $\begin{array}{c}\text { UAH } \\
\text { million }\end{array}$ & \% of GDP \\
\hline 2008 & 231686.3 & 24.44 & 241454.5 & 25.47 & 2732.5 & 0.29 & -12500.7 & $-1.32 \%$ \\
\hline 2009 & 209700.3 & 22.96 & 242437.2 & 26.54 & 2780.3 & 0.30 & -35517.2 & $-3.89 \%$ \\
\hline 2010 & 240615.2 & 22.23 & 303588.7 & 28.04 & 1292.0 & 0.12 & -64265.5 & $-5.94 \%$ \\
\hline 2011 & 314616.9 & 23.90 & 333459.5 & 25.33 & 4715.0 & 0.36 & -23557.6 & $-1.79 \%$ \\
\hline 2012 & 346054.0 & 24.56 & 395681.5 & 28.08 & 3817.7 & 0.27 & -53445.2 & $-3.79 \%$ \\
\hline 2013 & 339180.3 & 23.31 & 403403.2 & 27.73 & 484.7 & 0.03 & -64707.6 & $-4.45 \%$ \\
\hline 2014 & 357084.2 & 22.79 & 430217.8 & 27.46 & 4919.3 & 0.31 & -78052.8 & $-4.98 \%$ \\
\hline 2015 & 534694.8 & 27.01 & 576911.4 & 29.14 & 2950.9 & 0.15 & -45167.5 & $-2.28 \%$ \\
\hline 2016 & 616274.8 & 25.86 & 684743.4 & 28.73 & 1661.6 & 0.07 & -70130.2 & $-2.94 \%$ \\
\hline 2017 & 793265.0 & 26.59 & 839243.7 & 28.13 & 1870.9 & 0.06 & -47849.6 & $-1.60 \%$ \\
\hline 2018 & 928108.3 & 26.08 & 985842.0 & 27.70 & 1514.3 & 0.04 & -59247.9 & $-1.66 \%$ \\
\hline 2019 & 998278.9 & 25.12 & 1072891.5 & 26.99 & 3437.0 & 0.09 & -78049.5 & $-1.96 \%$ \\
\hline 2020 & 1076016.7 & & 1288016.7 & & 5096.1 & & -217096.1 & \\
\hline
\end{tabular}

State budget revenues in Ukraine formed mainly through various taxes and fees, control over the receipt of which entrusted to tax service.Implementation of the state budget revenue plan in January - September 2020 presented in Figure 1.

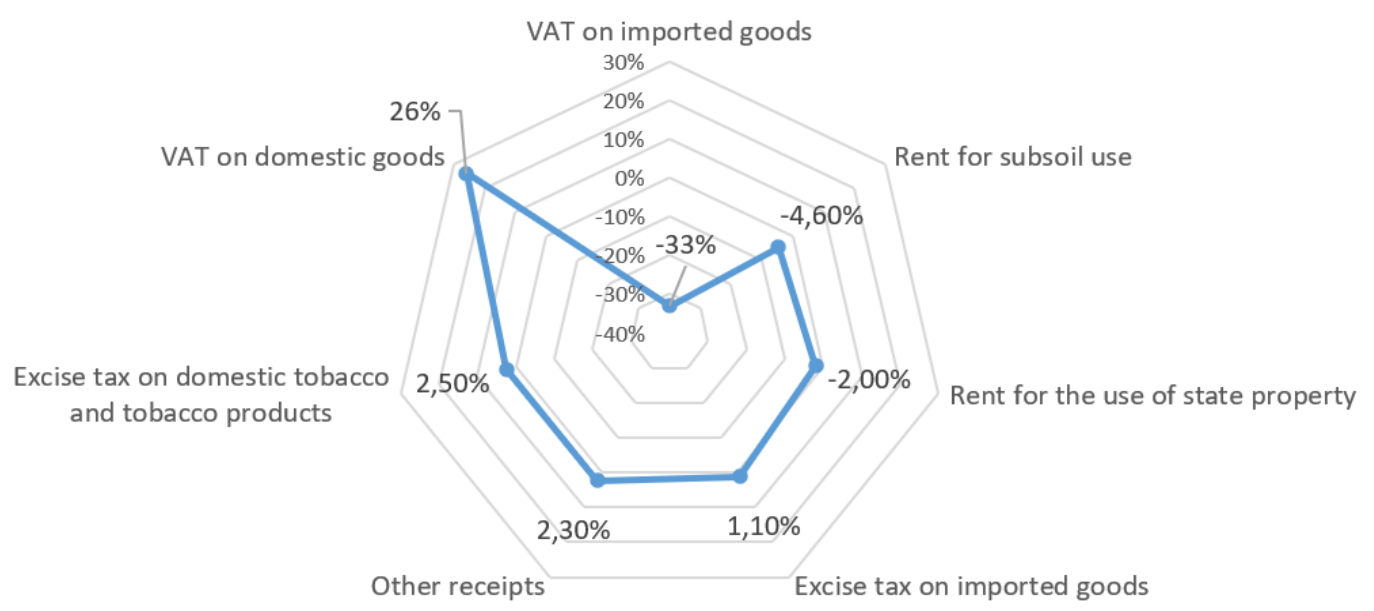

Figure 1. Implementation of the state budget revenue plan Ukraine (9 months 2020)

According to official statistics, the budget deficit - a chronic phenomenon in the economy of Ukraine. The budget deficit has usually estimated as a percentage of GDP. The budget deficit caused by the reduction of budget revenues and the growth of budget expenditures are one of the main factors of inflation. The amount of non-fulfillment of the plan for January-September of separate revenues of the general fund of the state budget made a total of 45 billion hryvnias. The plan of VAT receipts from goods imported into the customs territory of Ukraine was not fulfilled by $15.1 \%$, while the planned indicator of import duty receipts under the same conditions was not fulfilled only by $0.5 \%$. This indicates, first of all, the low quality of planning, ineffective tax control.The largest non-fulfillment of the planned indicators of revenues of the general fund of the state budget occurred in relation to the following payments: VAT on goods imported into the customs territory of Ukraine (12.7\%); corporate income tax (2.4\%); income from rent for the use of the entire property complex and other 
state property (68.7\%); rent for subsoil use (8.8\%).

The presence of a significant amount of tax debt to the state budget has a negative impact on the implementation of state budget revenues and indicates an unsatisfactory state of financial discipline of taxpayers and the lack of action taken by the authorities State tax service measures to manage tax debt. Thus, the further reorganization of the state tax service, which aimed at the latest concept of digitalization of public management - the creation of a service tax service of the European standard with a high level of trust in society (Miriam Lips et al., 2009) - is a timely and necessary measure to improve control over the state budget.

\section{Methodology}

To achieve the goal of this study, a system of general scientific and special methods and approaches was used, in particular: general scientific, interdisciplinary and special research methods. To build a methodological research basis and conceptual basis, a content analysis of scientific sources on the organization of accounting and control of calculations for tax liabilities of budgetary institutions was conducted. To understand the role of digitalization and digital technologies in the further transformation of accounting and tax control, in this paper they have conceptually considered as concepts consisting of the following elements: integrated information systems in accounting and control, big data and machine learning. Integrated information systems (Rom, A., \& Rohde; Quattrone, 2016) are those that involve the exchange of data between elements of the system with a certain frequency. Big data in the formation of the system of accounting and control of tax liabilities serve for the systematic submission of a growing amount of data, their availability, subject to constant growth (generation) of data. It is not only about increasing the amount of data, but also increasing the speed (timely updating) and variability (data types) as the defining criteria of big data (Gandomi \& Haider, 2015). Machine learning - the applied use of algorithms and statistical models by information systems, in order to continuously improve the quality and effectiveness of the accounting and control system (Mergel, 2019; Sagan et al., 2020). This approach related to the theories of statistical learning (Fishenden \& Thompson, 2013), when computer systems build functions based on data, evaluate and select their set for the most accurate predictions (models consisting of a large number of functions). This set of mathematical and statistical functions is a decision tree, where each node is a specific function, and predictions are the probable paths of the data. Under conditions of progress, the amount of data generated constantly increasing exponentially (World Bank, 2016), which requires transformational changes in the system of accounting and control, constant improvement of computing power of computer systems. To achieve this goal, a set of general scientific and special methods was used: the method of system analysis and formalization of complex structures; generalizations and scientific abstraction; statistical method of data processing, grouping method. In addition to general methods of scientific knowledge, the paper used specific methods of accounting, according to the National regulations (standards) of accounting in the public sector of Ukraine, and control in budgetary institutions. In particular, the following are continuous: continuous and local methods of control, generalization and implementation of control results. A study of the regulatory framework for the organization of accounting and control of calculations of tax liabilities of budgetary institutions in the context of transformational changes in fiscal institutions. International standards also analyzed, which implemented in the national practice of accounting in budgetary institutions of Ukraine. On the basis of the information presented by budgetary institutions practical cases of the organization of the account and control of calculations under tax obligations of budgetary institutions, examples of the decision of concrete situations and errors in the account considered.

\section{Evaluation and analysis of results}

\subsection{Specifics of the organization of accounting calculations for tax liabilities in budgetary organizations of Ukraine.}

Budgetary institutions conduct accounting in accordance with national regulations (standards) of 
accounting in the public sector and other regulations on accounting in the manner prescribed by the Ministry of Finance of Ukraine.

The Tax Code regulates relations arising in the field of collection of taxes and fees:

- determines the exhaustive list of taxes and fees paid in Ukraine, the procedure for their administration, payers of taxes and fees, their rights and obligations;

- determines the competence of controlling bodies, powers and duties of their officials during tax administration, as well as responsibility for violation of tax legislation.

Budget institutions have the status of non-profit organizations, according to the Tax Code of Ukraine. That is, a non-profit organization does not aim to make a profit. Therefore, the budgetary institution is not a payer of income tax. A prerequisite for non-profit organizations is the use of their income (profits) solely to finance the costs of their maintenance, implementation of goals (objectives, tasks) and activities defined by the constituent documents.

The amount of credit or non-repayable financial assistance received by a non-profit budgetary institution shall not be subject to taxation, provided that the estimate of such non-profit budgetary institution provides for the specified revenues.

In this case, income in the form of loan amounts or non-repayable financial assistance should be used exclusively to finance the costs provided for in the budget for the maintenance of such a nonprofit organization, the realization of goals (objectives, tasks) and activities defined by its constituent documents.

In the case of receiving amounts that are taxable income for other legal entities, for non-profit organizations the main thing is not the fact of receiving such income, but the direction of use of funds or other assets. If these funds used in accordance with the constituent documents, there are no grounds for revoking the non-profit status. As the status of "non-profit organization" have used exclusively in tax accounting, it in no way affects the accounting of such legal entities.

Non-profit organizations can be VAT payers if they carry out operations to supply goods or services in the customs territory of Ukraine. VAT is an indirect tax that accrued and paid in accordance with the provisions of the Tax Code of Ukraine.

Tax liability - the total amount of VAT received (accrued) by the taxpayer in the reporting (tax) period. A tax credit the amount by which a VAT payer has the right to reduce the tax liability of the reporting (tax) period.

For public sector entities today there is no separate legal document that defines the features of reflection in the accounting of business transactions for VAT calculations.

Therefore, budget managers must independently develop and use their own methods of accounting for VAT calculations, taking into account the main provisions of the Tax Code of Ukraine and other regulations.

The budget institution as a VAT payer as a result of business transactions according to the calculations at the end of the reporting month submits a VAT return in the appropriate form and the Procedure for approval, approved by the order of the Ministry of Finance from 28.01.16 № 21.

The declaration specifies the difference between the tax liability and the tax credit, and if the amount of tax liability exceeds the amount of the tax credit, then the institution must transfer the appropriate amount to the budget. In order to calculate this amount correctly, the institution must properly reflect business transactions.

The method of VAT accounting by public sector entities has its own characteristics, which distinguishes it from business entities. It should be noted that the main reason for these features is that to date no separate procedure for tax accounting has been approved for public sector entities. As a result, each budgetary institution that is a VAT payer has in the administrative document on accounting policy:

- prescribe the main VAT transactions and the nuances of their reflection in accordance with the 
norms of national standards and regulations on accounting in the public sector;

- identify sub-accounts and open analytical accounts for them to display information on VAT calculations.

When developing the work plan of the institution's accounts and analytical accounts should take into account all the conditions of recognition and reflection of the tax credit and tax liabilities in accounting.

When developing a working plan of the institution's accounts, in terms of VAT payments, we will take as a basis account 63 "Calculations for taxes and fees", designed to record and summarize information on calculations for taxes and fees (mandatory payments):

- the credit of account 63 reflects accrued payments to the budget for the payment of taxes and fees, etc., accrued liabilities for the single social contribution (SSC), as well as funds received from insurance agencies;

- by debit - their payment, debt repayment, write-off, etc.

Account 63 has sub-account 6311 "Settlements with the budget for taxes and fees", which records the settlements of the public sector entity with the budget for taxes and fees, which accrued and paid in accordance with the law.

To this sub-account we will open the following analytical accounts:

6311.1 "VAT liabilities have not confirmed". The amount of VAT, which included in the value of shipped goods / services and reflected in the income, should be reflected on the credit of this subaccount in correspondence with the debit of the relevant income accounts (7th class);

6311.2 "Tax liabilities for VAT confirmed". Here is the amount of VAT, which included in the value of shipped goods / services and reflected in the income and for which the Tax Invoice registered in the Unified Register of Tax Invoices (hereinafter - TI, URTI);

6311.3 "VAT tax credit unconfirmed". The amount of VAT included in the value of goods / services received has reflected on the debit of this sub-account, on which the tax credit recorded, in correspondence with the credit of the relevant accounts of liabilities for settlements with suppliers and contractors $(6211,2113)$;

6311.4 "Tax credit with VAT confirmed". Here the amount of VAT, which included in the value of received goods / services and for which the tax invoice registered in the Unified Register of Tax Invoices, is taken into account.

To record and summarize information on the availability and movement of funds placed, in particular, on accounts in the Treasury, the Procedure № 1219 provides for account 23 "Cash in accounts". The debit of this account reflects the receipt of funds on accounts in the Treasury, the credit - their use. This account has two sub-accounts:

2313 "Registration accounts" - to account for funds held in accounts with the Treasury and can be used for current operations;

2314 "Other accounts in the Treasury" - to account for other receipts of funds in the accounts with the Treasury and not reflected in sub-account 2313, in particular funds to be paid to hospital staff; funds allocated from the budget to the administrator of budget funds for their further distribution and transfer to registration accounts.

In order to detail the funds received, whether funding or own revenues, analytical accounts should be introduced in sub-account 2313:

2313.1 "General Fund";

2313.2 "Special Fund", including:

- 2313.2.1 "Receipt of the special fund according, ICC 25010100" (ICC - income classification code);

- 2313.2.2 "Expenditures of the special fund, ICC 25010100".

The movement of funds on the electronic account of the institution reflected on sub-account 2314. 
Funds, which, for example, will go to the electronic account to replenish and transferred by the Treasury to the budget to repay accounts payable (hereinafter - AP) for VAT liabilities, have accounted for separate analytical account, for example, 2314.1 "Calculations with the budget in e-administration system VAT ", which opened to sub-account 2314.

Budgetary institutions keep records of settlements with the budget for taxes and fees on subaccounts:

2110 "Accounts receivable for settlements with the budget" - for receivables (hereinafter - RV);

6311 "Settlements with the budget for taxes and fees" - for accounts payable for accrued taxes and fees paid in accordance with the law.

Therefore, to distinguish between potential debtors and creditors of the institution, sub-account 2110 can be used to account for the tax credit.

After all, if at first the goods / services were received or the funds were transferred for their purchase, then the recognition of the tax credit is the formation of receivables of the budget to the institution. However, the accounting of tax credit amounts confirmed by registered tax invoices in the Unified Register of Tax Invoices should be kept separately from unconfirmed ones.

To account for the tax credit provided sub-account 6311. In particular, the inclusion of VAT in the tax credit reflected by:

Dt 6311 - Kt 2113 "Settlements on advances issued to suppliers, contractors for goods, works and services", 6211 "Settlements with suppliers and contractors".

Given the accounting judgment, the use of sub-account 6311 to account for tax credit and tax liabilities is appropriate and logical, because the analysis of this sub-account immediately gives us the result between the tax credit and tax liabilities, which will be summarized on it.

Equally important is the identification of codes for the economic classification of budget expenditures (hereinafter - CECE) to determine the target direction of funds in the calculation of VAT. Payment of VAT included in the price of goods, works and services made according to the CECE for which the main payment is made, or for CECE 2800 "Other current expenses", if the tax payment related to the taxpayer's tax credit.

The reason - the amount of VAT has not included in the initial cost of manufactured products, purchased fixed assets and materials. Code 2800 incurs expenses not related to the purchase of goods and services by institutions, including: payment of tax, non-tax and other payments on a nonrefundable basis, the collection of which provided by law, including the amount of VAT not included in the cost, as the budgetary institution is a VAT payer.

Example. The budgetary institution registered as a VAT payer and maintained at the expense of the state budget. The institution performed the following operations:

- raw materials and materials for the manufacture of products for the total amount of UAH 12,000 were received from the supplier. (including VAT - UAH 2,000);

- in due time the supplier registered TI in URTI;

- materials were paid as a manager by the special fund of the state budget from the registration account opened with the Treasury;

- materials were used in production and products worth UAH 48,000 were manufactured. (including VAT - UAH 8,000).

The incurred expenses should be reflected through:

- CECE 2210 "Items, materials, equipment and inventory" in the amount of UAH 10,000.

- CECE 2800 - VAT in the amount of UAH 2,000.

As the tax invoice has registered in the Unified Register of Tax Invoices on time and properly, the budgetary institution has the right to include the amount of UAH 2,000 to the tax credit. According to the Standard correspondence, the purchase of raw materials has reflected in the accounting as shown 
Digital Technologies in the Organization of Accounting and Control of Calculations for Tax Liabilities of Budgetary Institutions

in table 2.

Table 2. Accounting entries with the reflection of VAT in correspondence for the purchase of raw materials in accounting budgetary institution

\begin{tabular}{|c|c|c|c|c|}
\hline \multirow[t]{2}{*}{ № } & \multirow[t]{2}{*}{ The content of the business transaction } & \multicolumn{2}{|c|}{$\begin{array}{c}\text { Correspondence of } \\
\text { sub-accounts }\end{array}$} & \multirow[t]{2}{*}{$\begin{array}{l}\text { Amount } \\
\text { UAH }\end{array}$} \\
\hline & & debit & credit & \\
\hline 1 & Raw materials and materials received from the supplier & 1517 & 6211 & 10000 \\
\hline 2 & $\begin{array}{l}\text { The amount of VAT reflected, if VAT included in the tax credit, not } \\
\text { confirmed by TI }\end{array}$ & 6311.3 & 6211 & 2000 \\
\hline 3 & $\begin{array}{l}\text { The amount of VAT reflected, if VAT included in the tax credit on the } \\
\text { basis of the TI registered in URTI received from the supplier }\end{array}$ & 6311.4 & 6311.3 & 2000 \\
\hline \multirow[t]{2}{*}{4} & $\begin{array}{l}\text { The cost of the received materials was paid at the expense of the } \\
\text { special fund: } \\
\text { - amount without VAT; }\end{array}$ & \multirow[t]{2}{*}{6211} & \multirow[t]{2}{*}{ 2313.2.2 } & 6000 \\
\hline & - VAT & & & 2000 \\
\hline \multirow{2}{*}{5} & \multirow{2}{*}{ The use of materials on the basis of the act is reflected } & 8113 & 1517 & 6000 \\
\hline & & 1613 & 8113 & 6000 \\
\hline
\end{tabular}

1517 - Raw materials; 8113 - Material costs; 1613 - Other production.

Finished products made of raw materials have accounted for as shown in table 3.

Table 3. Accounting entries with the reflection of VAT in correspondence on the movement of finished products in accounting budgetary institution

\begin{tabular}{|l|l|c|c|c|}
\hline \multirow{2}{*}{ № } & \multicolumn{1}{|c|}{ The content of the business transaction } & $\begin{array}{c}\text { Correspondence of sub- } \\
\text { accounts }\end{array}$ & $\begin{array}{c}\text { Amount, } \\
\text { UAH }\end{array}$ \\
\cline { 3 - 5 } & \multicolumn{1}{|c|}{ debit } & credit & \\
\hline 1 & Finished products have posted & 1811 & 1613 & 40000 \\
\hline 2 & $\begin{array}{l}\text { The amount of income from the sale of goods (including } \\
\text { VAT) accrued }\end{array}$ & 2111 & 7111 & 48000 \\
\hline 3 & $\begin{array}{l}\text { The amount of VAT, which is part of the cost of production, } \\
\text { accrued, the TI formed }\end{array}$ & 7111 & 6311.1 & 8000 \\
\hline 4 & $\begin{array}{l}\text { The cost of sold products is written off at the expense of } \\
\text { the institution }\end{array}$ & 8113 & 1811 & 40000 \\
\hline 5 & Receipts from the sale of goods & 2313.2 .1 & 2111 & 48000 \\
\hline 6 & Funds were credited from account 3125 to account 3522 & 2313.2 .2 & 2313.2 .1 & 48000 \\
\hline
\end{tabular}

1811 - Finished products; 2111 - Current receivables for payments for goods, works, services; 7111 - Income from sales of products (works, services).

The budgetary institution already has one registered TI received in the amount of UAH 2,000. But she needs to register a tax return with the amount of UAH 8,000 VAT. Therefore, in order to register a $\mathrm{TI}$ in the URTI, the institution must replenish the electronic account by UAH 6,000. (UAH 8,000 - UAH 2,000 ). In accounting, the replenishment of the electronic account, according to the Standard correspondence, has displayed as shown in table 4.

Table 4. Accounting entries reflecting the operations of replenishment of the electronic account of the budgetary institution

\begin{tabular}{|c|l|c|c|c|}
\hline \multirow{2}{*}{ № } & \multicolumn{1}{|c|}{ The content of the business transaction } & \multicolumn{2}{|c|}{$\begin{array}{c}\text { Correspondence of } \\
\text { sub-accounts }\end{array}$} & \multirow{2}{*}{$\begin{array}{c}\text { Amount, } \\
\text { UAH }\end{array}$} \\
\cline { 3 - 4 } 1 & \multicolumn{1}{|c|}{$\begin{array}{l}\text { The electronic invoice has been replenished to obtain the right to } \\
\text { register a tax return for sales tax }\end{array}$} & 2314.1 & 2313.2 .2 & 6000 \\
\hline 2 & The original TI was registered, which confirmed the tax liability & 6311.1 & 6311.2 & 8000 \\
\hline 3 & $\begin{array}{l}\text { The amount of tax liability confirmed by the amount of tax credit is } \\
\text { reduced }\end{array}$ & 6311.2 & 6311.4 & 2000 \\
\hline 4 & $\begin{array}{l}\text { Funds to the budget were written off based on the results of } \\
\text { submitting the declaration from the electronic account }\end{array}$ & 6311.2 & 2314.1 & \multirow{2}{*}{6000} \\
\hline
\end{tabular}


Reflecting business transactions on subaccounts of accounting, actual expenses have formed at withdrawal from the income from realization of the part of the VAT (8000 UAH), and cash - at payment to the supplier of cost of materials (2 $000 \mathrm{UAH})$ and at write-off from the VAT account. (UAH 6,000). At the end of the reporting period, the budget institution closes all accounts of revenues and expenditures for the financial result of the budget (table 5).

Table 5. Accounting entries reflecting the financial result of the budget of the budgetary institution

\begin{tabular}{|l|l|c|c|c|}
\hline \multirow{2}{*}{ № } & \multicolumn{1}{|c|}{ The content of the business transaction } & \multicolumn{2}{|c|}{$\begin{array}{c}\text { Correspondence } \\
\text { of sub-accounts }\end{array}$} & \multirow{2}{*}{$\begin{array}{c}\text { Amount, } \\
\text { UAH }\end{array}$} \\
\cline { 3 - 4 } & \multicolumn{1}{|c|}{$\begin{array}{l}\text { debit } \\
\text { credit }\end{array}$} & 7111 & 5511 & 40000 \\
\hline 2 & $\begin{array}{l}\text { Revenue from sales of products attributed to the financial result at } \\
\text { the end of the reporting period } \\
\text { material costs }\end{array}$ & 5511 & 8113 & 10000 \\
\hline
\end{tabular}

5511 - Financial result of the estimate of the reporting period.

According to national regulations (standards) of accounting in the public sector 124 "Income", the amount of VAT does not form income from exchange transactions. According to national regulations (standards) of accounting in the public sector 135 "Expenses", expenses recognized simultaneously with the recognition of income for which they have incurred. In view of this, the cost of goods sold without the amount of VAT is written off. When reflecting VAT transactions in the accounting of a budgetary institution, the working plan of accounts developed and approved by the order on accounting policy should be used, with the allocation of analytical accounts to sub-account 6311 . In the administrative document, it is advisable to provide a complete list of accounts and sub-accounts for which the budgetary institution will make calculations with VAT, and to detail the analytical accounts of its own work plan of accounts. Thus, the organization of accounting calculations for tax liabilities in budgetary organizations has a number of features that have based on regulations on accounting and reporting in budgetary organizations, as well as their industry specifics. The specific features of accounting in a budgetary institution are as follows:

- the branch of budgetary activity has the features of the account, control and regulation of accounting policy;

- budgetary institutions work according to the plan of accounts, reports and documentation different from commercial organizations;

- based on the organization of budget accounting - budget classification in terms of certain items;

- the budget organization uses strict accounting and control of expenditure and profit transactions;

- has its own characteristics of the organization of accounting for tangible assets that have been purchased from various financial sources;

- the formation and implementation of the budget is hierarchical in nature, associated with the treasury system of the state;

- regulated control by state institutions over the implementation of the plan of financial and economic activities of the budget organization.

\subsection{Information and analytical resource to control the calculations of tax liabilities of budgetary institutions of Ukraine}

According to the results of the annual study Paying Taxes 2020, which estimates the ease of paying taxes in 190 countries, Ukraine took 65th place and lost 11 points recently. Trends of the current stage of development of the tax system are active actions of governments around the world to automate processes and reduce the time of tax administration, as well as increasing the fiscal burden on business. Thanks to automation and maximum simplification of procedures, for example, Turkey has significantly improved its ratings (from 80 to 20 steps), abolishing VAT on capital investments, which has eliminated the need for businesses to spend time on its reimbursement. Hungary (rising from 86th to 56th position in 2020) significantly reduced the duration of the audit of income tax reporting adjustments. In some countries (Portugal, France, Poland, Lithuania) real-time reporting to the tax 
authorities has been introduced, which has optimized processes. A pilot project on the use of blockchain technologies for VAT administration has been launched in Kazakhstan. A similar project is being launched by the British government.

Optimization measures for the use of existing IT systems have helped Brazil and Vietnam achieve a record reduction in VAT time. Instead, Ukraine is in the preparatory stage of digitalization of tax authorities and reform of tax administration. The main problem is the large amount of time for tax accounting - on average, business spends 328 hours per year, which is twice as much as in developed countries, the duration of VAT accounting Ukraine ranks 176 out of 190.

In Ukraine since 2019 a new stage in the tax policy of the state began. The Cabinet of Ministers of Ukraine has transferred to the State Tax Service the functions of implementing the state tax policy. The State Tax Service was established as a result of the reorganization State Fiscal Service of Ukraine(2018). The main function of the Statetax service there is a tax control, which consists in exercising control over:

- compliance with tax legislation,

- the correctness of calculation, completeness and timeliness of payment to the budgets of taxes, fees and other payments and non-tax revenues and contributions to state trust funds established by the legislation of Ukraine.

The new tax service has designed to become a reliable partner with taxpayers, implementingan effective mechanism for cooperation between regulatory authorities and business, new services and ensure equal rights for all taxpayers. Among the general changes taking place in the system of state financial control, the main transformations are: elimination of technical and logical errors, streamlining of functions and definition of controlling bodies in connection with reorganization of the state fiscal service of Ukraine and improvement of e-cabinet functioning, in particular:

- expansion of the list of documents that can be obtained through the e-office (notification of refusal to accept his tax return, some documents on the results of inspections, individual tax consultations, etc.);

- clarification of the procedure for delivery of the document in electronic form to the payer through the electronic office;

- providing payers with the opportunity to submit an electronic message (with documentary evidence) to correct inaccurate, incomplete or outdated information about themselves, access to which has provided to him through the electronic office;

- settlement of organizational processes related to the formation and acceptance of reports submitted by electronic means in electronic form.

The following have introduced into the activity of the tax service:

- new Internet technologies (the web portal of the tax service has been improved, an information Internet platform for taxpayers has been created, an electronic document management system has been introduced);

- modern methods of explanatory work (video seminars, webinars, Internet conferences, etc.), the purpose of which is to improve the process of accepting electronic reporting, get the necessary services, certificates or information online.

The introduction of the electronic service should minimize the contacts of taxpayers with taxpayers, eradicate corruption in the state tax service, create convenient conditions for the taxpayer to calculate taxes. That is, transformational changes affect priorities: unpopular fiscal measures are replaced by new, progressive actions of the tax service, which aim to expand the range of services and improve the quality of service to taxpayers. In order to create a modern information-analytical resource of the tax service, the need to develop and implement information systems and networks adapted to the needs of taxpayers actualized. The structure of the information and analytical resource of the tax service presented in Figure 2. 


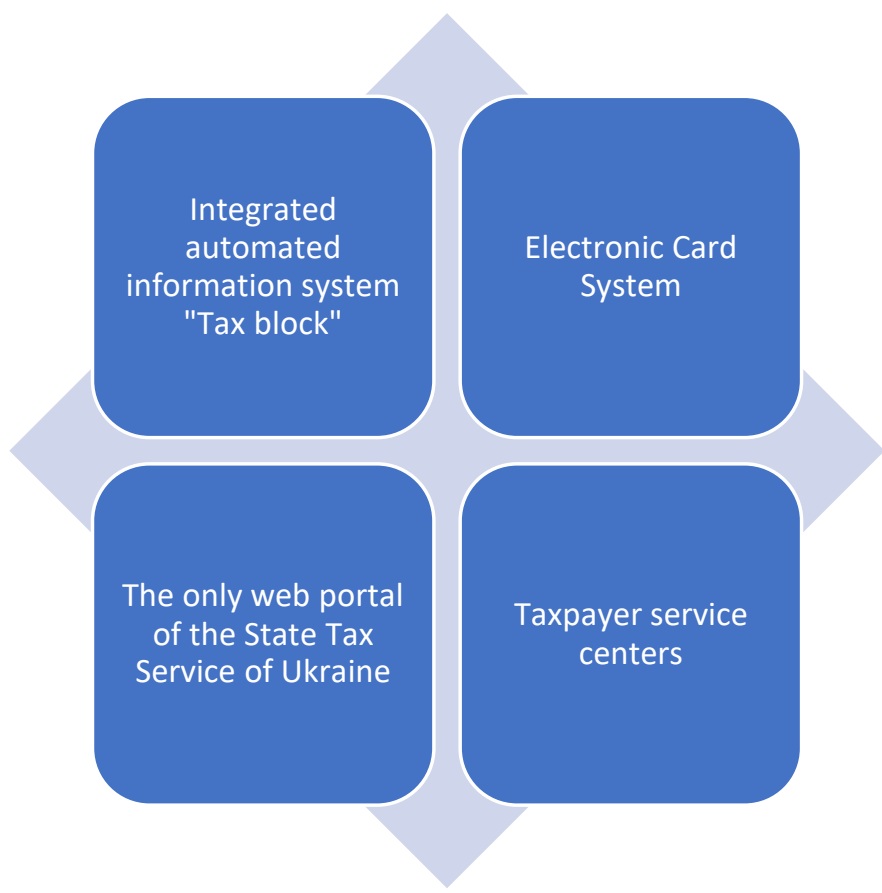

Figure 2. Components of the information and analytical resource of the tax service

Currently, the tax service is forming an integrated automated information system "Tax block", system "Electronic card", a single web portal of the state tax service of Ukraine, service centers for taxpayers. The components of the "Tax Block" are presented in Figure 3.

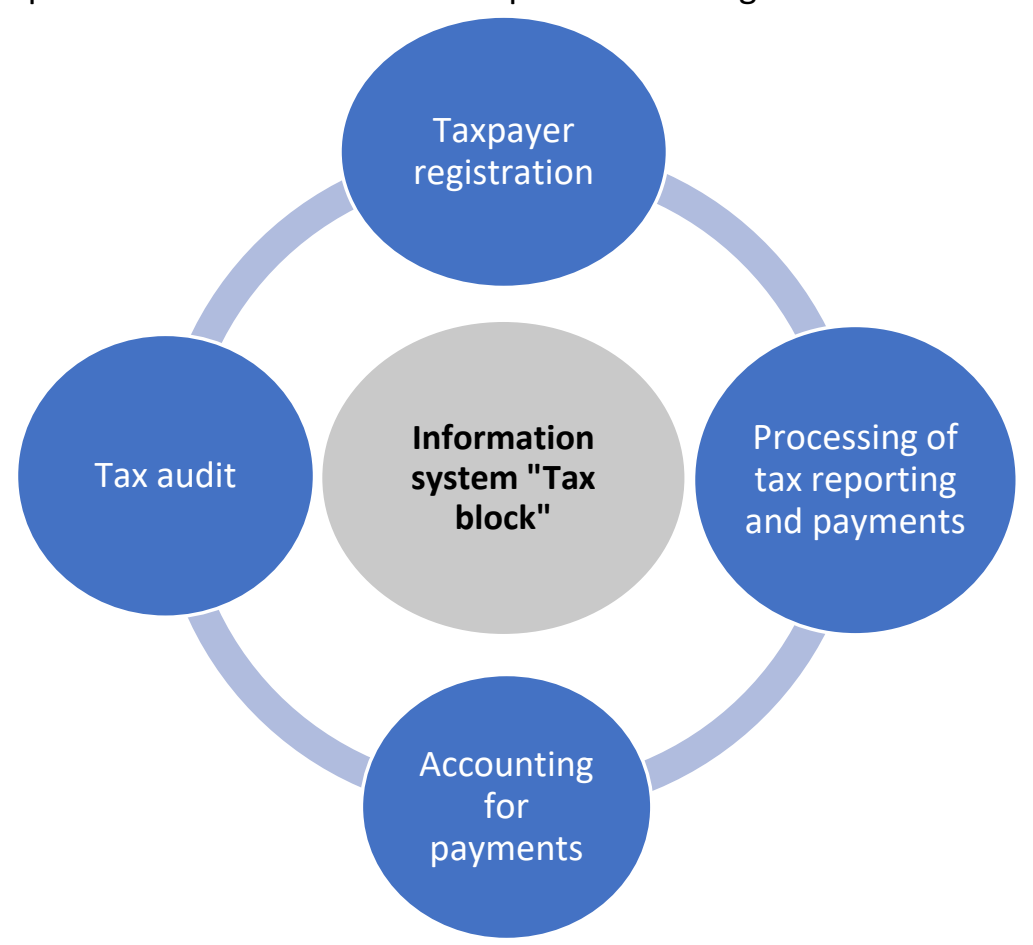

Figure 3. Segments of operational activities of the tax service as part of the information system "Tax Block"

The operational activity of the tax service provided by the following segments, which are components of the information system "Tax Block": registration of taxpayers; processing of tax reports and payments; accounting of payments; tax audit in the form of modernized procedures (forms), software, job descriptions, training.

The subsystem "Registration of taxpayers" provides the implementation of the procedure for registration of taxpayers. At the same time, an electronic exchange of information with other bodies of state executive power formed. 
Such a system of interaction strengthens tax control, as it provides the ability to obtain complete and accurate data on taxable persons (taxpayers) and objects of taxation.

The subsystem "Processing of tax reporting and payments" works on the basis of scanning technology and provides efficiency and accuracy of input and processing of tax reporting data in real time (online).

This minimizes the likelihood of errors by the taxpayer.

This subsystem is a feedback channel with the taxpayer. The taxpayer may review information on the status of its settlements with the budget, as well as pay taxes, fees (mandatory payments).

Through this channel you can submit documents: complaints, letters, applications, in particular, for registration as a taxpayer of certain types of taxes, for obtaining certificates, original documents, etc.

The subsystem "Tax Audit", as an element of tax control, helps to identify taxpayers who minimize their tax liabilities.

A risk-oriented system of tax administration has been created on the basis of this subsystem. Such a tool will reduce the interference of the state tax service in the business activities of taxpayers, detecting malicious violators of tax legislation.

It is assumed that the introduction in Ukraine of electronic cards as a unified means of payment with multi-level protection against reading, forgery and the likelihood of criminal fraud will be convenient to use throughout Ukraine.

This will provide an opportunity to create favorable conditions for taxpayers to fulfill their tax obligations on a voluntary basis: remotely, with individual services and with the qualified assistance of central level specialists. In particular, the taxpayer with the help of a personal computer / smartphone (at home, at work, on the road) online using an electronic digital signature will be able to conduct such transactions with his own personal e-office, such as consulting, submission of registration data, submission of reports in electronic form,

Currently, the E-office is a secure, personalized and secure electronic service that provides contactless ways of interaction between taxpayers and the state tax service using modern information and communication technologies.

This simplifies the administration of taxes and interaction with regulatory authorities, while reducing the administrative burden on regulatory authorities, reducing costs.

Ukraine is introducing terminals for self-service of taxpayers using the automated system "Electronic Card", which will ensure data consistency and the appropriate level of protection of tax information at all stages of its life cycle, as well as pay taxes from current bank accounts of taxpayers. One of the priorities is the transformation of the tax service from a fiscal body into a customer-oriented public service.

To implement such projects, payer service centers have been established.

The main tasks of the centers are the introduction of standardized and transparent forms and methods of servicing taxpayers, ensuring efficiency in issuing permits, improving the efficiency of administration of taxes and fees, improving the process of receiving reports from businesses, and ensuring quick access to information (Shahzad et al 2019).

Thus, the whole range of services for the administration of taxes and fees - registration, provision of administrative services for the issuance of certificates and incoming correspondence - is concentrated in one place for the comfort of taxpayers.

The organization of the process of accounting and control of calculations for tax liabilities of budgetary institutions can be significantly improved with the introduction of digital technologies, combining each element of new technologies (Table 6).

Thus, the use of Internet technologies in the state tax service creates more convenient conditions for taxpayers to use their tax liabilities on a voluntary basis, remotely, with individual services and with the qualified assistance of central level specialists. The use of such services allows the control systemto 
make calculations on tax liabilities of budgetary institutions transparent and effective.

Table 6. The effects of the introduction of digital technologies in the organization of accounting and control of calculations for tax liabilities of budgetary institutions

\begin{tabular}{|c|c|c|c|c|}
\hline Accounting and control processes & Cloud & Al & Big Data & Blockchain \\
\hline $\begin{array}{l}\text { efficient storage and processing of large amounts of accounting } \\
\text { and tax data }\end{array}$ & + & & + & \\
\hline automation of accounting processes & + & + & & + \\
\hline ensuring the highest quality of accounting information & & + & + & + \\
\hline automation of customer verification / customer information & + & & + & + \\
\hline forecasting tax revenues & + & + & + & + \\
\hline strengthening the fight against tax fraud and tax evasion & + & + & + & + \\
\hline improving the audit and accuracy of regulatory reporting & + & + & + & + \\
\hline $\begin{array}{l}\text { assessment of tax risks with the exception of incorrect conclusions } \\
\text { for regulatory authorities }\end{array}$ & + & + & + & + \\
\hline control of transfer pricing in the context of preventing tax evasion & & + & & + \\
\hline $\begin{array}{l}\text { reimbursement of taxes paid to the payer on the basis of a } \\
\text { preliminary analysis of its legality }\end{array}$ & & + & & + \\
\hline tax consulting and forecasting services based on identified trends & & + & & \\
\hline $\begin{array}{l}\text { identification of types of tax behavior based on clustering of } \\
\text { taxpayers through the study of their costs and tax characteristics }\end{array}$ & & + & & \\
\hline automation of the process of taxation of complex taxes & & + & & \\
\hline $\begin{array}{l}\text { solving problems in the tax sphere for taxpayers based on the } \\
\text { analysis of options offered by artificial intelligence }\end{array}$ & & + & & \\
\hline ensuring fiscalization of settlement and cash transactions. & + & + & + & + \\
\hline $\begin{array}{l}\text { conducting tax accounting, control and exchange of information } \\
\text { in real time }\end{array}$ & + & + & + & + \\
\hline quick and effective ways to assess and settle tax liabilities & + & + & + & + \\
\hline $\begin{array}{l}\text { modernization of tax management and counteraction to } \\
\text { fraudulent technologies }\end{array}$ & + & + & + & + \\
\hline $\begin{array}{l}\text { real-time transactions by businesses will reduce the time between } \\
\text { transaction reporting and tax payment }\end{array}$ & + & + & + & + \\
\hline administration of indirect taxes & + & + & + & + \\
\hline $\begin{array}{l}\text { reduction of tax disputes between regulatory authorities and } \\
\text { taxpayers, as a significant part of them is based on the arguments } \\
\text { of the parties on the historical aspect of the transactions carried } \\
\text { out by the taxpayer }\end{array}$ & + & + & + & + \\
\hline $\begin{array}{l}\text { increase the transparency of transactions based on smart } \\
\text { contracts that automate transactions under certain conditions, in } \\
\text { particular, reducing prices below a given level }\end{array}$ & + & + & + & + \\
\hline $\begin{array}{l}\text { reduction of document flow, simplification of accounting and } \\
\text { reporting }\end{array}$ & + & + & + & + \\
\hline data integrity & + & + & + & + \\
\hline
\end{tabular}

\section{Conclusion}

This study examines the main tools of digital technologies in the organization of accounting and control, which can be effectively applied at all stages of tax administration and optimize activitiesall participants in tax relations. It is proved that the introduction of digital technologies will help reduce paperwork, simplify accounting and reporting for taxpayers. Thanks to digital technologies, the economic activity of taxpayers will become more transparent for tax authorities, the assessment of tax risks will be optimized and the opportunities for detecting tax fraud will increase. The creation of a modern information and analytical resource of the tax service optimizes the system of accounting and control, which will lead to the introduction of more effective mechanisms for tax administration, deshadowing of the economy and increasing control over cash flow. Digitalization in the organization of accounting and control of settlements for tax liabilities and the process of servicing taxpayers will 
increase the level of tax culture.

\section{References}

1. About the Sustainable Development Strategy "Ukraine - 2020". URL: https://zakon.rada.gov.ua/laws/show/5/2015\#Text. (15.02.2021).

2. ACCA/IMA (2013). Digital Darwinism: Thriving in the Face of Technology Change. URL: https://www.accaglobal.com/in/en/technical-activities/technical-resourcessearch/2013/october/digital-darwinism.html. (15.02.2021).

3. Accenture (2018). CFO reimagned - From bottom line to front line. URL: https://www.accenture.com/t20180910T083815Z_w__us-en/_acnmedia/PDF-85/AccentureCFO-Research-Global.pdf. (15.02.2021).

4. Al-Htaybat, K., \& Von Alberti-Alhtaybat, L. (2017). Big Data and corporate reporting: Impacts and paradoxes. Account Audit Accountability, 30, 850-873. https://doi.org/10.1108/Aaaj-07-20152139.

5. Alghamdi, A., \& Akbar, M. (2017). Profiling and Evaluation of Implicit and Explicit Storm Surge Models. Int. J. Comput. Theory Eng, 9, 417-421.

6. Appelbaum, D., Kogan, A., Vasarhelyi, M., \& Yan, Z. K. (2017). Impact of business analytics and enterprise systems on managerial accounting. International Journal of Accounting Information Systems, 25, 29-44. https://doi.org/10.1016/j.accinf.2017.03.003.

7. Bhimani, A., \& Willcocks, L. (2014). Digitisation, 'Big Data' and the transformation of accounting information. Accounting and Business Research, 44, 469-490. https://doi.org/10.1080/00014788.2014.910051.

8. Bondarenko, S., Ivanchenkova, L., Okhrimenko, O., Zybareva, O., Karpitskaya, M., \& Huz, M. (2020). Risk Management of Enterprise Restructuring Strategy. International Journal of Advanced Research in Engineering and Technology. 11(5). 14-25.

9. Bondarenko, S., Tkach, I., Drobotov, S., Mysyk, A., \& Plutytska, K. (2021). National Resilience as A Determinant of National Security of Ukraine. Journal of Optimization in Industrial Engineering, 14(1), 111-117. https://doi.org/10.22094/JOIE.2020.677837

10.Brown, A. D. (2019). Identities in organization studies. Organizational Studies, 40, 7-22. https://doi.org/10.1177/0170840618765014.

11.Byrne, S., \& Pierce, B. (2007). Towards a more comprehensive understanding of the roles of management accountants. European Accounting Review, 16, 469-498. https://doi.org/10.1080/09638180701507114.

12.Caglio, A. (2003). Enterprise Resource Planning systems and accountants: Towards hybridization? European Accounting Review, 12, 123-153. https://doi.org/10.1080/0963818031000087853.

13.Chandi, N. (2018). Accounting trends of tomorrow: What you need to know. Forbes. URL: https://www.forbes.com/sites/forbestechcouncil/2018/09/13/accounting-trends-of-tomorrowwhat-you-need-to-know/?sh=2901b617283b (15.02.2021).

14.Cho, J.S., Ahn, S., \& Jung, W. (2018). The impact of artificial intelligence on the audit market. Korean Account. J., 27, 289-330.

15.Christauskas, C. \& Misevicience, R. (2012). Cloud computing based accounting for small to medium sized business. Inz. Ekon. Eng. Econ., 23, 14-21.

16.Clarke, A. (2020). Digital government units: what are they, and what do they mean for digital era public management renewal?, International Public Management Journal, 23:3, 358-379, DOI: 10.1080/10967494.2019.1686447

17.Dechow, N., \& Mouritsen, J. (2005). Enterprise resource planning systems, management control and the quest for integration Accounting. Organizations and Society, 30, 691-733. https://doi.org/10.1016/j.aos.2004.11.004. 
18.Deloitte (2017). The New Machinery of Government: Robotic Process Automation in the Public Sector. URL:

http://www2.deloitte.com/content/dam/Deloitte/uk/Documents/Innovation/deloitteukinnovation-the-new-machinery-of-govt.pdf (15.02.2021).

19.Dunleavy, P., Margetts, H., Bastow, S., \& Tinkler, J. (2006). Digital Era Governance-IT Corporations, the State and e-Government. New York: Oxford University Press. 289 pp.

20.Eklund, S., Tam, M., \& Woodcock, E. (2018). New technology, new rules: Reimagining the modern finance workforce. Mckinsey. URL: https://www.mckinsey.com/businessfunctions/operations/our-insights/new-technology-new-rules-reimagining-the-modern-financeworkforce. (15.03 2019).

21.European-Commission. (2016). Europe's digital progress report. EU - European Comission. URL:http://ec.europa.eu/newsroom/dae/document.cfm?action=display\&doc_id=17338. $\quad$ (11.12 2016).

22. Execution of the state budget of Ukraine. URL: https://index.minfin.com.ua/ua/finance/budget/gov/2020/ (15.02.2021)

23.Fishenden, J., \& M. Thompson. (2013). Digital Government, Open Architecture, and Innovation: Why Public Sector IT Will Never Be the Same Again. Journal of Public Administration Research and Theory, 23 (4), 977-1004. https://doi.org/10.1093/jopart/mus022.

24.FSB (Financial Stability Board). (2017). Artificial Intelligence and Machine Learning in Financial Services: Market Developments and Financial Stability Implications. URL: http://www.fsb.org/wpcontent/uploads/P011117.pdf (15.02.2021).

25.Gandomi, A., \& Haider, M. (2015). Beyond the hype: Big data concepts, methods, and analytics. International Journal of Information Management, 35, 137-144. https://doi.org/10.1016/j.ijinfomgt.2014.10.007.

26.Goretzki, L., \& Messner, M. (2019). Backstage and frontstage interactions in management accountants' identity work Accounting. Organizations and Society, 74, 1-20. https://doi.org/10.1016/j.aos.2018.09.001.

27.Goretzki, L., Lukka, K., \& Messner, M. (2017). Controllers' use of informational tactics. Accounting and Business Research, 48, 700-726. https://doi.org/10.1080/00014788.2017.1407627

28.Holmgren Caicedo, M., Mårtensson, M., \& Tamm Hallström, K. (2018). The development of the management accountant's role revisited: An example from the Swedish Social Insurance Agency. Financial Accountability \& Management, 34, 240-251. https://doi.org/10.1111/faam.12156.

29. Horton, K. E., \& Wanderley, C. D. (2018). Identity conflict and the paradox of embedded agency in the management accounting profession: Adding a new piece to the theoretical jigsaw. Management Accounting Research, 38, 39-50. https://doi.org/10.1016/j.mar.2016.06.002.

30.IFAC (2019). Technology and the Profession-A Guide to ICAEW's Work. 2019. URL: https://www.ifac.org/knowledge-gateway/preparing-future-readyprofessionals/discussion/technology-and-profession-guide-icaew-s-work (15.02.2021).

31.Ionescu, B., Ionescu, I., Bendovschi, A., \& Tudoran, L. (2013). Traditional accounting vs. cloud accounting. In Proceedings of the 8th International Conference Accounting and Management Informational Systems, Bucharest, Romania, 12-13 June 2013, pp. 106-125.

32.Mavlutova, I., Babenko, V., Dykan, V., Prokopenko, N., Kalinichenko, S., Tokmakova, I. (2021). Business Restructuring as a Method of Strengtening Company's Financial Position. Journal of $\begin{array}{llll}\text { Optimization in Industrial } & \text { Engineering, 14(1), }\end{array}$ http://dx.doi.org/10.22094/JOIE.2020.677839

33.Mergel, Ines. (2019). "Digital Service Teams in Government." Government Information Quarterly, August, 101389. https://doi.org/10.1016/j.giq.2019.07.001.

34.Moll, J., \& Yigitbasioglu, O. (2019). The role of internet-related technologies in shaping the work of 
accountants: New directions for accounting research. The British Accounting Review. https://doi.org/10.1016/j.bar.2019.04.002.

35. On the establishment of the State Tax Service of Ukraine and the State Customs Service of Ukraine (2018). https://zakon.rada.gov.ua/laws/show/1200-2018-\%D0\%BF\#Text. (15.02.2021).

36.Perevozova, I., Daliak, N., Babenko, V. (2019). Modeling of Financial Support for the Competitiveness of Employees in the Mining Industry. CEUR Workshop Proceedings, vol. 2422, pp. 444-454. URL: http://ceur-ws.org/Vol-2422/paper36.pdf

37.Peter, J., \& Robinson, P. (2014). Civic Hackathons: Innovation, Procurement, or Civic Engagement?: Civic Hackathon: Procurement or Civic Engagement? Review of Policy Research 31(4), 349-57. https://doi.org/10.1111/ropr.12074.

38.Phillips, B.A. (2012). How Cloud Computing Will Change Accounting Forever. URL: https://docplayer.net/2537016-How-the-cloud-will-change-accounting-forever.html. (15.02.2021).

39.Podgorna, I., Babenko, V., Honcharenko, N., Sáez-Fernández, F. J., Fernández, J. A. S., Yakubovskiy, S. (2020). Modelling and Analysis of Socio-Economic Development of the European Union Countries through DP2 Method. WSEAS Transactions on Business and Economics, Volume 17, Art. \#44, pp. 454-466. https://doi.org/10.37394/23207.2020.17.44

40.Quattrone, P. (2016). Management accounting goes digital: Will the move make it wiser? Management Accounting Research, 31, 118-122. https://doi.org/10.1016/j.mar.2016.01.003.

41.Rieg, R. (2018). Tasks, interaction and role perception of management accountants: evidence from Germany. Journal of Management Control, 29, 183-220. https://doi.org/10.1007/s00187-0180266-0.

42.Rikhardsson, P., \& Yigitbasioglu, O. (2018). Business intelligence \& analytics in management accounting research: Status and future focus. International Journal of Accounting Information Systems, 29, 37-58. https://doi.org/10.1016/j.accinf.2018.03.001.

43.Rom, A., \& Rohde, C. (2007). Management accounting and integrated information systems: A literature review. International Journal of Accounting Information Systems, 8, 40-68. https://doi.org/10.1016/j.accinf.2006.12.003.

44.Sagan, O., Yakovleva, S., Anisimova, E., Balokha, A., \& Yeremenko, H. (2020). Digital didactics as a new model in the theory of education. Revista Inclusiones, 7 (num Especial), 193-204.

45.Shahzad, B., \& Crowcroft, J. (2019). Trustworthy electronic voting using adjusted blockchain technology. IEEE Access, 7, 24477-24488.

46.Schaltegger, S., \& Zvezdov, D. (2015). Gatekeepers of sustainability information: exploring the roles of accountants. Journal of Accounting \& Organizational Change, 11, 333-361. https://doi.org/10.1108/jaoc-10-2013-0083.

47.Sudomyr, S., Niziaieva, V., Lutay, L., Prodanova, L., Havryliuk, O. \& Sherstyukova K. (2020). Methods And Techniques of Motivation of Subjects of Regional Economy For Innovative Improvement. International Journal of Scientific \& Technology Research. 9(3). 1196-11200.

48.Shaikh Asadullah, YousefAsiri, and Sulaiman.AdelA. (Editorial)Evaluating CriticalMeasures of Quality Management and Quality Control. 2020 International Journal for Quality Research, Vol. 14, No. 4, pp.985-988. Scopus and $\mathrm{ESCl}$ indexed

49.Strategy for public administration reform in Ukraine until 2021. URL: https://zakon.rada.gov.ua/laws/show/ru/474-2016-\%D1\%80\#Text (25.12.2017)

50.Ulanoff, Lance. (2017). "Should We Be Worried about the Future of the U.S. Digital Service?" Mashable, April 24. URL: http://mashable.com/2017/04/24/the-future-of-the-us-digital-service/ (15.02.2021).

51.Weber, J. (2011). The development of controller tasks: explaining the nature of controllership and its changes Journal of Management. Control, 22, 25-46. https://doi.org/10.1007/s00187-011-0123- 
$\mathrm{x}$.

52.Wolf, S., Weißenberger, B. E., Claus Wehner, M., \& Kabst, R. (2015). Controllers as business partners in managerial decision-making. Journal of Accounting \& Organizational Change, 11, $24-46$. https://doi.org/10.1108/jaoc-10-2012-0100.

53.World Bank. (2016). World Development Report 2016: Digital Dividends. World Bank, Washington DC. License: Creative Commons Attribution CC BY 3.0 IGO. https://doi.org/10.1596/978-1-46480671-1. 